\title{
Synthesis and Characterization of Fly Ash and GBFS Based Geopolymer Material
}

\author{
Dipankar Das 1,*iD , Prasanta Kumar Rout 1,* \\ 1 Department of Material Science and Engineering, Tripura University (A Central University) Suryamaninagar, Agartala, \\ Tripura, India-799144 \\ * Correspondence: dipankar.msen@tripurauniv.in (D.D); prasantarout@tripurauniv.in (P.K.R); \\ Scopus Author ID 56085442200
}

Received: 7.02.2021; Revised: 3.03.2021; Accepted: 7.03.2021; Published: 23.03.2021

\begin{abstract}
This study investigates the synthesis and characterization of fly ash and GBFS based material using geopolymer technology. Geopolymer is a class of inorganic polymer that can be formed by the reaction between an aluminosilicate source material and an alkaline solution. The geopolymer materials are synthesized, where the GBFS are added with fly ash in some specific ratios such as 100:0, 30:70, 50:50, 70:30, and 0:100, respectively. Sodium hydroxide $(\mathrm{NaOH})$ and sodium silicate $\left(\mathrm{Na}_{2} \mathrm{SiO}_{3}\right)$ solutions are used as alkaline solutions. $\mathrm{NaOH}$ concentration was kept at 14 molars, and the ratio of liquid to solid is kept at 0.3 . The specimens are cured at $60{ }^{\circ} \mathrm{C}$ for 24 hours. The hardened geopolymer specimens were tested by a digital compression testing machine and characterized by the FESEM technique. The hybrid C-N-A-S-H gel is the main reaction product for the fly ash and GBFS based geopolymer specimen, which plays an important role in compressive strength development.
\end{abstract}

Keywords: fly ash; GBFS; environment; geopolymer; characterization; FESEM.

(C) 2021 by the authors. This article is an open-access article distributed under the terms and conditions of the Creative Commons Attribution (CC BY) license (https://creativecommons.org/licenses/by/4.0/).

\section{Introduction}

Joseph Davidovits, a French scientist, first used the term "Geopolymer" in 1978 to represent the inorganic polymeric material from industrial waste [1, 2]. Geopolymers are a promising technology that uses aluminosilicate source material such as fly ash, GBFS, red mud, etc., and an alkaline solution to make a three-dimensional product. This technology can play a vital role in the context of sustainability and solves various environmental issues generated due to industrial waste. Geopolymer exhibits excellent properties such as fire resistance, high mechanical strength, low shrinkage, good thermal resistivity, and acid resistance, etc. [3-5]. Due to such properties Geopolymers are gaining much more attention from scientists and academicians nowadays. It emits 80 to $90 \%$ less $\mathrm{CO}_{2}$ to the environment as compared to OPC production [6]. The production process of a geopolymer also requires very little energy.

Industrialization plays an important role in the economic growth of any country. Due to industrialization, the electricity demand increases day by day, and coal is used as a prime source of fuel in a thermal power plant. The usage of coal as a fuel is increasing day by day in various developing countries, and as a result, millions of tons of fly ash are being generated around the globe. Improper combustion of coal in thermal power plants leads to fly ash generation, and the properties of coal fly ash are mainly dependant on various factors such as the type of coal used, the ash content in coal, combustion method, and type of boiler. Indian coal is 35 to $38 \%$ ash content, but the percentage of ash in imported coal is 10 to $15 \%$ [7, 8]. 
This fly ash powder causes various effects on the environment, such as air, water pollution. Large land area is also required for the dumping and disposal of fly ash, and it is highly unsustainable for the environment. Global fly ash generation is about 800 million tons, and India produced 217.04 million tons from 2018 to 2019 [9]. The utilization of fly ash in India for 2018 to 2019 is 168.40 million tons [10]. Ground granulated blast furnace slag (GBFS) is another important industrial by-product produced during pig iron making in the blast furnace of steel making plant. Every year millions of tons of fly ash are being generated worldwide. Disposal and management of the gigantic coal fly ash powder is a matter of concern. The disposal of fly ash in landfills causes serious environmental pollution such as air pollution, soil pollution, surface and groundwater pollution, and a serious threat to human health $[11,12]$. The disposal of coal fly ash powder in landfills also diminishing the valuable fertile land. Fly ash powder is one of the sources of aluminosilicate material. The amorphous silica and alumina, along with sub-micron particle size and shapes, make fly ash powder favorable or suitable for making geopolymeric material [13]. It has been reported that the main reaction product in the fly ash-based geopolymer is N-A-S-H $\left(\mathrm{N}-\mathrm{Na}_{2} \mathrm{O}, \mathrm{A}-\mathrm{Al}_{2} \mathrm{O}_{3}, \mathrm{~S}-\mathrm{SiO}_{2}\right.$, and $\left.\mathrm{H}-\mathrm{H}_{2} \mathrm{O}\right)$ gel as observed in SEM [14]. In natural curing at room temperature, the FA-based geopolymer shows low reactivity, which results in low setting time and low strength gain [15-17]. To avoid this issue and to get better strength, the fly ash particles are processed by mechanical activation $[14,18]$ and also by the addition of ground granulated blast furnace slag (GBFS) [17]. GBFS is another industrial by-product obtained by quenching molten iron slag from a blast furnace in steel plants. GBFS has pozzolanic and cementitious properties. This granular product is dried and ground into a fine powder by using a ball mill. The main product formed by the reaction between slag and alkaline activator is calcium silicate hydrate along with the aluminum (Al) in the structure, which is also known as C-A-S-H $\left(\mathrm{C}-\mathrm{CaO}, \mathrm{A}-\mathrm{Al}_{2} \mathrm{O}_{3}, \mathrm{~S}-\mathrm{SiO}_{2}\right.$ and $\left.\mathrm{H}-\mathrm{H}_{2} \mathrm{O}\right)$ gel [17, 19]. The main limitation of the alkali-activated slag-based geopolymer is poor workability and fast setting time. To get rid of this situation, there could be a possibility to synthesized a geopolymer by blending both FA and GBFS powder by activating with alkaline activators. This leads to the formation of binding gels of $\mathrm{Na}_{2} \mathrm{O}-\mathrm{CaO}-\mathrm{Al}_{2} \mathrm{O}_{3}-\mathrm{SiO}_{2}$ and shows better mechanical strength as a comparison to the specimen prepared with the alkali-activated FA powder [20].

Saha et al. studied the enhancement of the properties of FA-based geopolymer by adding GBFS. It was reported that the initial and final setting time is reduced significantly with the increase of GBFS, and the compressive strength is increased with the increase of the $\mathrm{NaOH}$ concentration along with the incorporation of GBFS. The highest compressive strength of 78.2 MPa was achieved with $16 \mathrm{M} \mathrm{NaOH}$ solution and $50 \%$ GBFS [21]. Samantasinghar et al. investigated the influence of curing environment in FA-GBFS based geopolymer. It was reported that the addition of GBFS in fly ash improves the strength at a lower temperature, and early strength can be achieved by microwave power by evenly distributing the heat [22]. Oderji et al. investigated the effect of slag and alkali activators on fresh and hardened properties of one part FA-based geopolymer and reported that the incorporation of slag content increases the mechanical strength such as compressive strength and flexural strength but decrease the workability of the geopolymer paste. It was also reported that the reduction of $\mathrm{Na}_{2} \mathrm{SiO}_{3}$ solution in the geopolymer binder significantly reduces the compressive strength [23]. Gong et al. reported that the addition of GBFS in fly ash-based geopolymer improves the compressive strength and setting time which was confirmed by the co-existence of sodium aluminosilicate gel or geopolymer gel (N-A-S-H gel) and aluminum-modified calcium silicate hydrate gel (C- 
A-S-H) [24]. So it can be concluded that the incorporation of GBFS in fly ash-based geopolymer plays an important role in the development of mechanical strength and setting time as well.

The objective of this present investigation is to characterize the as received raw material such as fly ash and GBFS powder, respectively. The fly ash and GBFS based geopolymer material are fabricated by using geopolymer technology. The mechanical testing of geopolymer specimens was done using a digital compression testing machine. The observed compressive strength data of geopolymer specimens was explained with the study of the microstructural features using a field emission scanning electron microscope (FESEM).

\section{Materials and Methods}

The raw materials used in this present study are class $\mathrm{F}$ fly ash powder from National Thermal Power Corporation Limited (NTPC), Bongaigaon, Assam, India, and ground granulated blast furnace slag (GBFS) was collected from the Shree Cement Limited, Raipur, Chhattisgarh, India. The as-received GBFS lumps are first dried in an oven to remove the moisture present in the material. Initially, the size of the lump was $0.5 \mathrm{~mm}$ to $4 \mathrm{~mm}$. The conventional ball mill machine was used to produce fine powder to enhance the reactivity of the material. The ball mill's weight in the ball mill was $25 \mathrm{~kg}$, where the ball diameter was 20 $\mathrm{mm}$ to $100 \mathrm{~mm}$, and $2 \mathrm{~kg}$ GBFS lump was given to the machine to run for 2 hours. Sodium hydroxide $(\mathrm{NaOH})$ pellets where minimum assay was $97.0 \%$ (make: Loba Chemie, India) and sodium silicate $\left(\mathrm{Na}_{2} \mathrm{SiO}_{3}\right)$ solution minimum assay of $97.0 \%$ (make: Loba Chemie, India) was used as an alkaline activator. The sodium silicate composition was $\mathrm{SiO}_{2}-25-28 \%$ and $\mathrm{Na}_{2} \mathrm{O}$ of 7.5-8.5\%. The pellets of sodium hydroxide were mixed with the required amount of doubledistilled water to produce the sodium hydroxide solution, where the concentrations are maintained at 14 molars $(14 \mathrm{M})$. We know that the molecular weight of the sodium hydroxide is $40 \mathrm{gm} / \mathrm{mol}$. So if we want to make $1 \mathrm{M} \mathrm{NaOH}$ solution, then we need to add $40 \mathrm{gm}$. of $\mathrm{NaOH}$ pellets or flakes to $1000 \mathrm{ml}$ double distilled water. The dissolution of $\mathrm{NaOH}$ pellets in water produces heat due to an exothermic reaction. So, the solutions were prepared at least one day before use and store in a glass container at room temperature to get a stable solution [25]. To enhance the geopolymerization reaction, the sodium silicate solution was used with sodium hydroxide solution [26]. The mass ratios of $\mathrm{Na}_{2} \mathrm{SiO}_{3} / \mathrm{NaOH}$ were kept constant at 1.0 , and the liquid to solid (alkaline activator/ fly ash powder) mass ratio was kept constant at 0.3 throughout the experiment.

The X-ray fluorescence (XRF) spectroscopy (model: AXIOS, make: PANalytical) and a laser diffraction-based particle size analyzer (model: MASTERSIZER, make: Malvern, UK) was used to measure the chemical composition and particle size distribution, respectively. To determine the different phases present in the raw materials, X-ray diffraction (model: X'pert PRO, make: PANalytical) was used. The functional group of raw materials was measured by using Fourier transform infrared spectroscopy (make: BRUKER, model: ALPHA T) with iD5 attenuated total reflectance (ATR) Accessory. The spectral range was between $500 \mathrm{~cm}^{-1}$ to $4000 \mathrm{~cm}^{-1}$, where the resolution was kept at $4 \mathrm{~cm}^{-1}$. The raw material powder morphology was observed using field emission scanning electron microscopy (Model: Sigma-300, make: Carl Zeiss) equipped with an energy dispersive X-ray spectrometer. The gold sputter coater was used to coat the powder by which the image instability and arching can be eliminated during the collection of micrographs. 


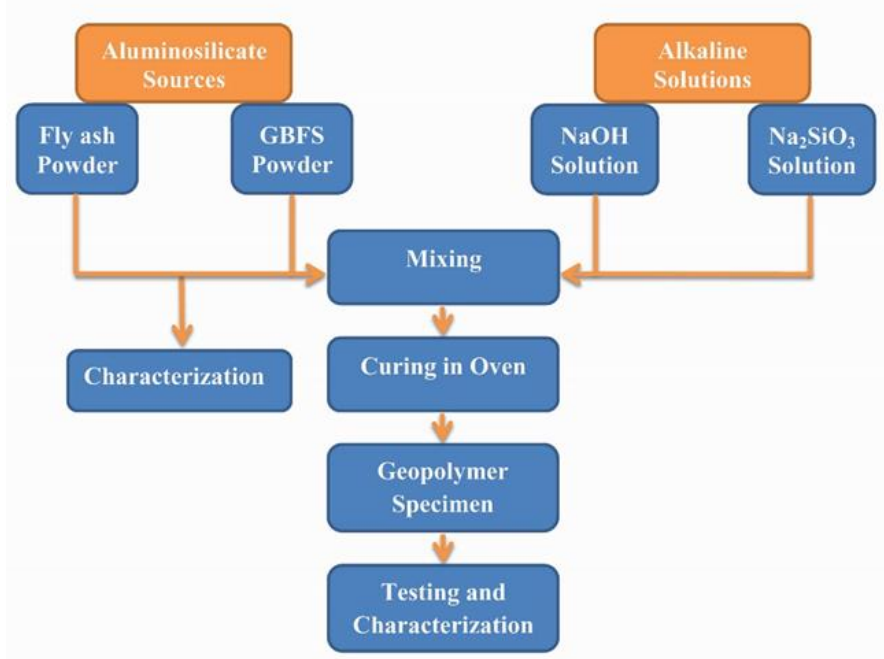

Figure 1. Process flow sheet of geopolymer specimen preparation.

The process flow sheet of geopolymer specimen preparation is shown in Figure 1. The fly ash and GBFS powder was mixed at an appropriate weight. After mixing, the sodium hydroxide solution was mixed with the raw material for a few minutes, and the sodium silicate solutions are added in a calculated amount. The obtained paste was cast in a cylindrical plastic mold and kept at room temperature for 24 hours. After 24 hours, the specimens were covered with a transparent plastic sheet and cured in the oven at a temperature of $60{ }^{\circ} \mathrm{C}$ for 24 hours [27]. The cured specimens are removed from the oven and kept at room temperature until the test. Table 1 shows the mixed design of geopolymer paste.

Table 1. Mix design of geopolymer paste.

\begin{tabular}{|c|c|c|c|c|c|c|c|c|c|}
\hline \multirow[t]{2}{*}{$\begin{array}{l}\text { Sl. } \\
\text { No. }\end{array}$} & \multirow[t]{2}{*}{$\begin{array}{l}\text { Specimen } \\
\text { ID }\end{array}$} & \multirow{2}{*}{$\begin{array}{c}\text { Concentration } \\
(\mathrm{NaOH}) \\
\text { solution }\end{array}$} & \multirow{2}{*}{$\begin{array}{c}\mathrm{Na}_{2} \mathrm{SiO}_{3} \\
/ \\
\text { NaOH } \\
\text { Ratio }\end{array}$} & \multicolumn{2}{|c|}{$\begin{array}{l}\text { Starting } \\
\text { powder }\end{array}$} & \multicolumn{2}{|c|}{ Alkaline solution } & \multirow{2}{*}{$\begin{array}{l}\text { Liquid/ } \\
\text { Solid } \\
\text { ratio }\end{array}$} & \multirow[t]{2}{*}{$\begin{array}{c}\text { Curing } \\
\text { Condition }\end{array}$} \\
\hline & & & & $\begin{array}{l}\text { FA } \\
\text { (g) }\end{array}$ & $\begin{array}{c}\text { GBFS } \\
\text { (g) }\end{array}$ & $\begin{array}{c}\mathrm{NaOH} \\
\text { solution } \\
\text { (g) }\end{array}$ & $\begin{array}{c}\mathrm{Na}_{2} \mathrm{SiO}_{3} \\
\text { Solution } \\
\text { (g) }\end{array}$ & & \\
\hline 1 & $\begin{array}{c}\text { FA-GBFS } \\
100-0\end{array}$ & 14 & 1 & 100 & 0 & 15 & 15 & 0.3 & \multirow{5}{*}{$\begin{array}{c}60^{\circ} \mathrm{C} \text { for } 24 \\
\text { hours }\end{array}$} \\
\hline 2 & $\begin{array}{c}\text { FA-GBFS } \\
30-70\end{array}$ & 14 & 1 & 30 & 70 & 15 & 15 & 0.3 & \\
\hline 3 & $\begin{array}{c}\text { FA-GBFS } \\
50-50 \\
\end{array}$ & 14 & 1 & 50 & 50 & 15 & 15 & 0.3 & \\
\hline 4 & $\begin{array}{c}\text { FA-GBFS } \\
70-30\end{array}$ & 14 & 1 & 70 & 30 & 15 & 15 & 0.3 & \\
\hline 5 & $\begin{array}{c}\text { FA-GBFS } \\
0-100\end{array}$ & 14 & 1 & 0 & 100 & 15 & 15 & 0.3 & \\
\hline
\end{tabular}

Note: FA indicates fly ash and GBFS indicates ground granulated blast furnace slag with appropriate ratio.

\section{Results and Discussion}

The color of fly ash and GBFS is light grey and white, respectively. Table 2 listed the various physical characteristics of fly ash and GBFS powder. The oxide composition of fly ash and GBFS are listed in table 3. From table 3, it can be observed that the weight percentage of $\mathrm{SiO}_{2}$ and $\mathrm{Al}_{2} \mathrm{O}_{3}$ is 55.6 and 29.80, along with $\mathrm{CaO}$ 1.59. The sum of $\mathrm{SiO}_{2}$ and $\mathrm{Al}_{2} \mathrm{O}_{3}$ is 85.4. This implies that the fly ash powder is of class F type per American society for testing and materials code ASTM C618 [28]. Few minor elements such as Magnesium (Mg), Titanium (Ti), Potassium (K), Sodium (Na), Manganese (Mn), Strontium (Sr), Zinc (Zn), Sulphur (S), etc. are also present in this fly ash. The weight percentage of $\mathrm{Fe}_{2} \mathrm{O}_{3}$ is 5.91. GBFS powder is having $\mathrm{SiO}_{2}$ and $\mathrm{Al}_{2} \mathrm{O}_{3}$ of 32.42 and 16.70 weight percentages along with $\mathrm{CaO}$ of 37.02. Some 
minor elements such as Iron (Fe), Magnesium $(\mathrm{Mg})$, Sulphur (S), etc., are also present in GBFS. The loss of ignition (LOI) in fly ash and GBFS is less than 0.47 and 1.75 , respectively.

Table 2. Physical properties of fly ash powder and GBFS powder.

\begin{tabular}{l|c|c}
\multirow{2}{*}{\multicolumn{1}{c|}{ Properties }} & \multicolumn{2}{c}{ Materials } \\
\cline { 2 - 3 } & Fly ash powder & GBFS powder \\
\hline Colour & Light grey & White \\
\hline $\mathrm{pH}$ & 7.4 & 10.43 \\
\hline Particle size $\left(\mathrm{d}_{90}\right)$ & $13.62 \mu \mathrm{m}$ & $51.45 \mu \mathrm{m}$ \\
\hline Particle size $\left(\mathrm{d}_{50}\right)$ & $2.54 \mu \mathrm{m}$ & $11.29 \mu \mathrm{m}$ \\
\hline Particle size $\left(\mathrm{d}_{10}\right)$ & $0.29 \mu \mathrm{m}$ & $0.38 \mu \mathrm{m}$
\end{tabular}

Table 3. Oxide composition (wt. \%) of FA and GBFS powder.

\begin{tabular}{c|c|c|c} 
Sl. No. & Oxides & FA powder & GBFS powder \\
\hline 1 & $\mathrm{SiO}_{2}$ & 55.6 & 32.42 \\
\hline 2 & $\mathrm{Al}_{2} \mathrm{O}_{3}$ & 29.80 & 16.70 \\
\hline 3 & $\mathrm{CaO}$ & 1.59 & 37.02 \\
\hline 4 & $\mathrm{Fe}_{2} \mathrm{O}_{3}$ & 5.91 & 0.97 \\
\hline 5 & $\mathrm{TiO}_{2}$ & 1.63 & ----- \\
\hline 6 & $\mathrm{MgO}$ & 1.08 & 8.37 \\
\hline 7 & $\mathrm{~K}_{2} \mathrm{O}$ & 1.94 & ----- \\
\hline 8 & $\mathrm{Na}_{2} \mathrm{O}$ & 0.23 & ---- \\
\hline 9 & $\mathrm{MnO}$ & 0.05 & ----- \\
\hline 10 & $\mathrm{SrO}$ & 0.04 & ----- \\
\hline 11 & $\mathrm{ZnO}$ & 0.03 & ----- \\
\hline 12 & $\mathrm{SO}$ & 0.45 & 0.15 \\
\hline 13 & $\mathrm{LOI}_{3}$ & 0.47 & 1.75
\end{tabular}

Note: LOI* $=$ loss of ignition.

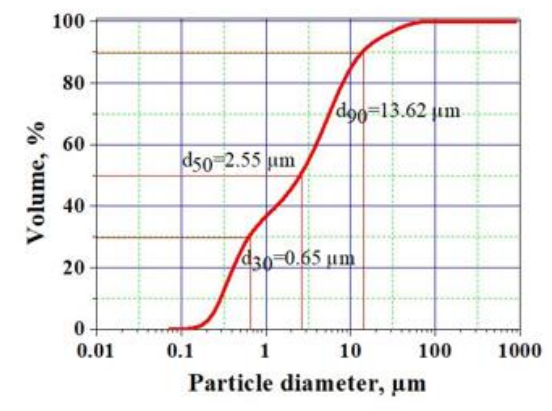

(a)

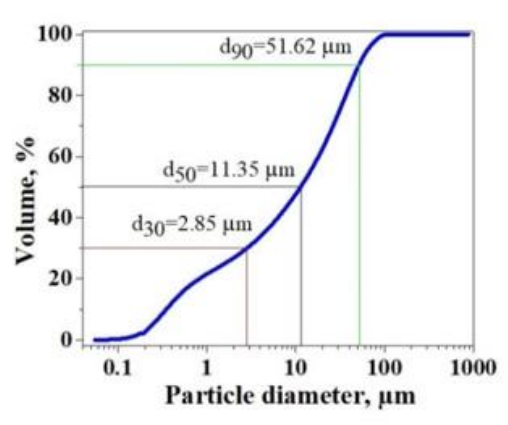

(b)

Figure 2. Particle size distribution of (a) Fly ash powder, (b) GBFS powder.

Particle size distribution (PSD) is one of the important physical properties which plays a vital role in the geopolymerization process. Figure 2(a) shows the particle size distribution of fly ash powder and GBFS powder, respectively. From Figure 2(a), it can be observed that the fly ash powder used for this present investigation was of good fineness with all particles are less than $100 \mu \mathrm{m}, 90$ volume $\%$ particles (d90) are less than $13.62 \mu \mathrm{m}, 50$ volume $\%$ particles $\left(\mathrm{d}_{50}\right)$ are under the size of $2.54 \mu \mathrm{m}, 10$ volume \% particles $\left(\mathrm{d}_{10}\right)$ are under the size of $0.29 \mu \mathrm{m}$. Figure 2(b) shows that the GBFS powder used in this investigation was of good fineness, with all particles are less than $112.8 \mu \mathrm{m} .90$ volume \% particles ( $\left.\mathrm{d}_{90}\right)$ are less than $51.45 \mu \mathrm{m}, 50$ volume \% particles $\left(\mathrm{d}_{50}\right)$ of milled slag under the size of $11.29 \mu \mathrm{m} .10$ volume \% particles $\left(\mathrm{d}_{10}\right)$ of the milled slag were under the size of $0.38 \mu \mathrm{m}$. We know that the finer particles, the greater the surface area and the reactivity $[29,30]$. 


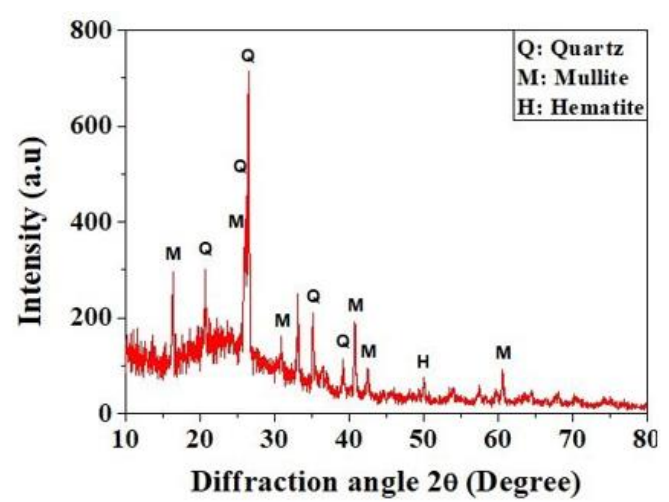

(a)

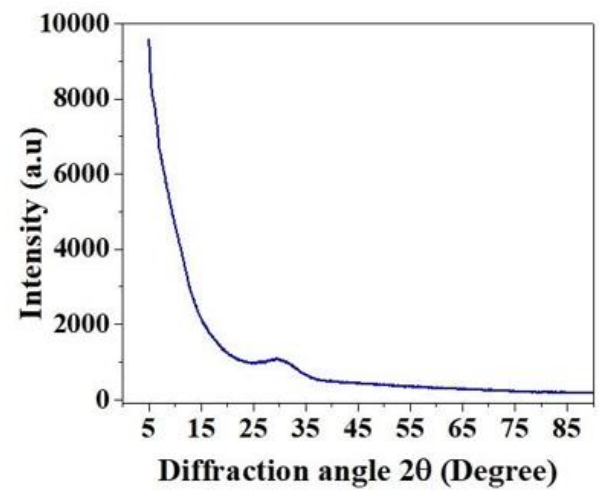

(b)

Figure 3. X-ray diffraction pattern of (a) Fly ash powder, (b) GBFS powder.

Fly ash typically refers to inorganic chemical compounds, both crystalline and noncrystalline. Crystalline and non-crystalline are the constituents that react and control fly ash's initial behavior when it comes in contact with the alkaline solution. Figure 3(a) shows the Xray diffraction pattern of as-received fly ash powder. Quartz and mullite are the major crystalline phases present in fly ash powder and minor phase hematite. The presence of quartz, mullite, and hematite are represented by Q, M, and H in Figure 3(a). Figure 3(b) shows the XRD pattern of GBFS powder. The presence of board hump in the range of $25^{\circ}$ to $35^{\circ}$ can be seen in it. This hump attributes to the presence of an amorphous (glassy) phase. The results of XRD pattern of the GBFS powder are consistent with the previous study done by various authors. [31, 32]. It was previously calculated from a quantitative XRD analysis that $97.7 \%$ of this GBFS is amorphous in nature, along with negligible crystalline content [33].
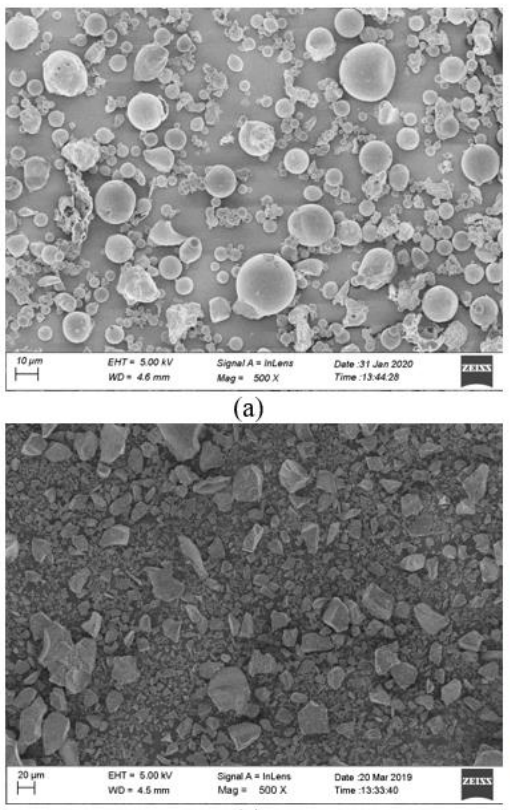

(c)

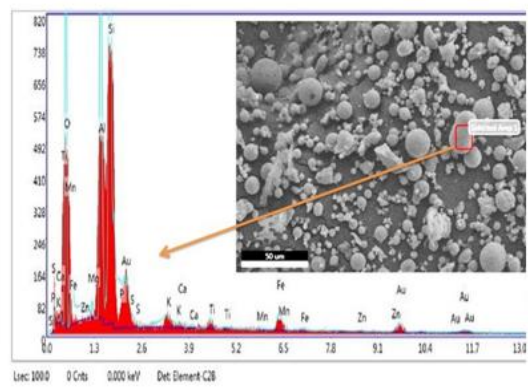

(b)

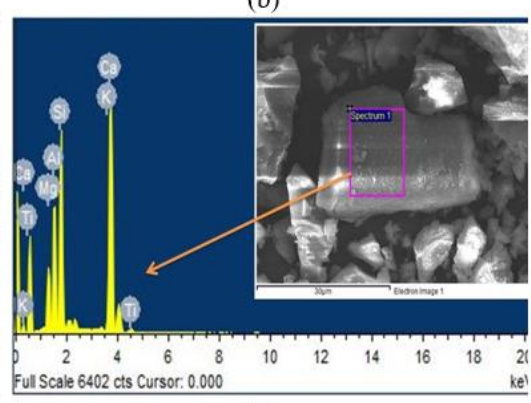

(d)

Figure 4. Morphology and energy-dispersive X-ray spectroscopy of (a and b) Fly ash powder, (c and d) GBFS powder.

Figure 4 shows the morphology and energy-dispersive X-ray spectroscopy of fly ash and GBFS powders. Figure 4(a), SEM micrograph of fly ash powder shows mostly round and spherical shapes with the smooth texture of different particle sizes. Further, it exhibits a very small amount of angular and irregular-shaped particles with a conglomeration of spherical particles. Figure 4(c), SEM micrograph of GBFS powder shows mostly irregular flake, 
anomalous shape with angular and sharp edges particle look like broken glasses. Energydispersive X-ray spectroscopy analysis was done on the powder sample to identify the various elements present in the starting raw material. From Figure 4(b), it can be seen that $\mathrm{Si}, \mathrm{Al}$ are the major constituents present along with minor constituents. The major constituent, namely $\mathrm{Ca}, \mathrm{Si}$, and $\mathrm{Al}$, are present in the GBFS powders and minor constituents, which can be observed from Figure 4(d).

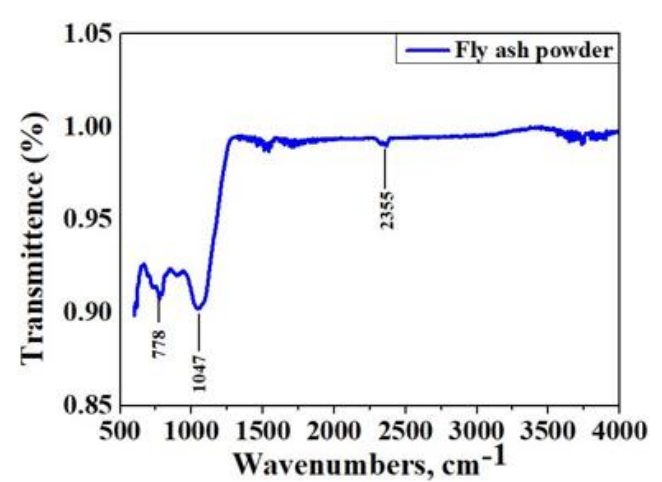

(a)

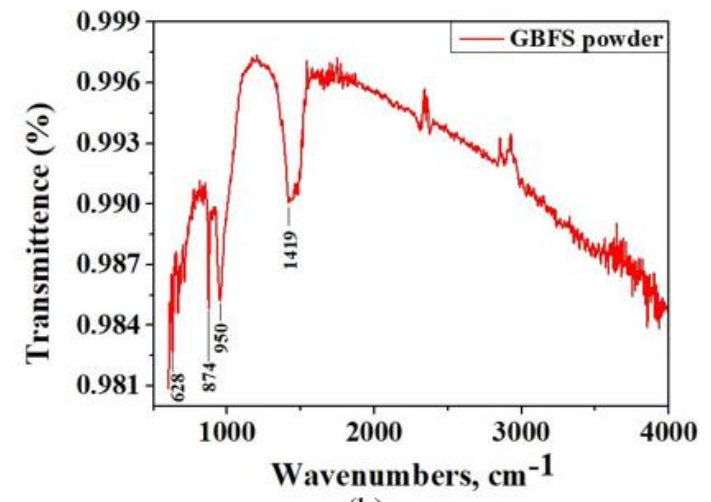

(b)

Figure 5. Fourier transform infrared spectra of (a) Fly ash powder, (b) GBFS powder.

Figure 5 shows the Fourier transform infrared spectra of unreacted fly ash and GBFS powder. The infrared spectrum of both the materials contains various broad bands that indicate tetrahedral $\mathrm{SiO} 4$ and $\mathrm{AlO} 4$ groups' internal vibrations. Figure 5(a) shows the bands at 778, 1047, and $2355 \mathrm{~cm}^{-1}$, and Figure 5(b) shows the bands at 628, 874, 950, and $1419 \mathrm{~cm}^{-1}$. The band observed at $1047 \mathrm{~cm}^{-1}$ in the fly ash powder and $950 \mathrm{~cm}^{-1}$ in the slag powder associated with T-O's asymmetric stretching vibrations $(\mathrm{T}=\mathrm{Si}, \mathrm{Al})$ [34]. The bands in the ranges of 1422 to $1427 \mathrm{~cm}^{-1}$ indicate the presence of carbonates [34]. The presence of quartz is attributed to the symmetric stretching band of $778 \mathrm{~cm}^{-1}$ in fly ash powder [35-37].

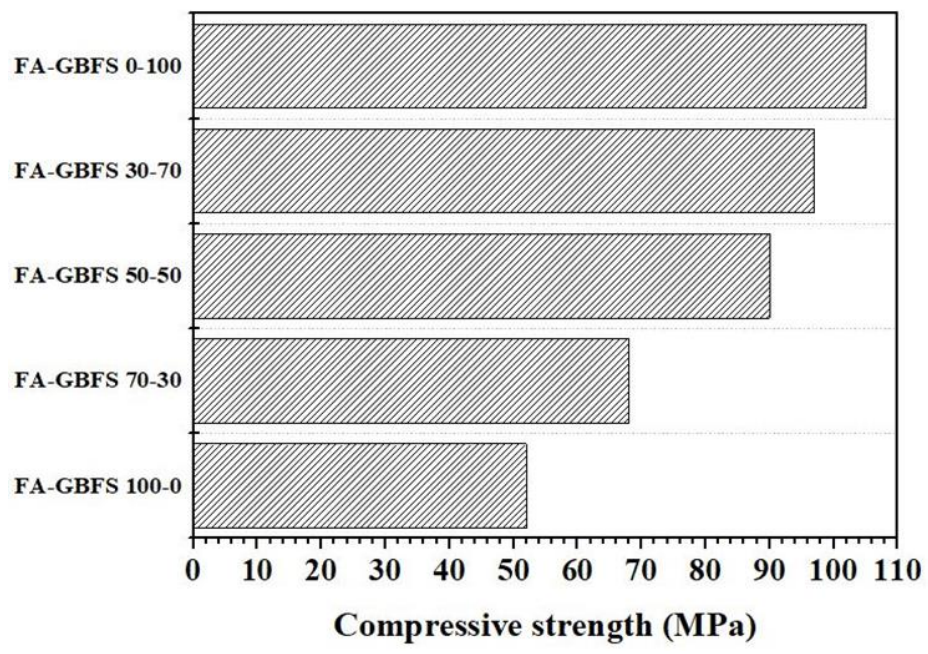

Figure 6. Compressive strength of geopolymer specimens.

Figure 6 shows the compressive strength of geopolymer specimens. The specimen (FAGBFS 100-0 and FA-GBFS 0-100), which are prepared with only fly ash powder, slag, and alkaline solution, shows the compressive strength of $52 \mathrm{MPa}$ and $105 \mathrm{MPa}$, respectively. The specimen's ID FA-GBFS 75-25, FA-GBFS 50-50, and FA-GBFS 25-75 show the compressive strength of $68 \mathrm{MPa}, 90 \mathrm{MPa}$, and $97 \mathrm{MPa}$. The reaction time for specimen ID FA-GBFS 1000 is very slow, but the reaction time for specimen ID FA-GBFS 0-100 is quick. To eliminate 
this issue, the GBFS powders are added to fly ash powder in an appropriate ratio. The main reaction product for fly ash-based geopolymer and ground granulated blast furnace slag-based geopolymer is N-A-S-H gel and C-A-S-H gel, respectively. The addition of GBFS in fly ashbased geopolymer improved the compressive strength that is due to the C-A-S-H gel formation [17]. The presence of soluble calcium content in the GBFS also directly affects the compressive strength [38]. The presence of N-A-S-H and C-A-S-H gels or hybrid C-N-A-S-H gel is the main reaction product for the fly ash and ground granulated blast furnace slag-based geopolymer [35]. Curing temperature and curing time also plays a vital role in improving the compressive strengths of geopolymeric specimen [39].

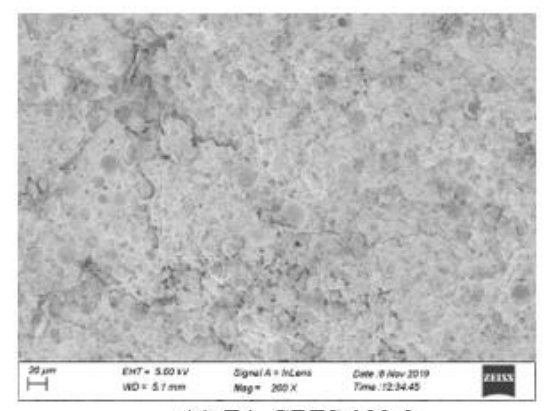

(a) FA-GBFS $100-0$

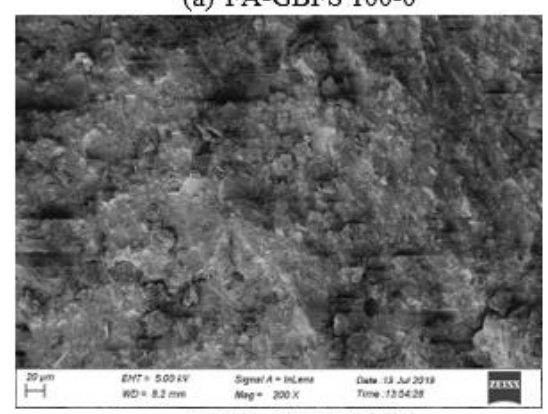

(c) FA-GBFS 50-50

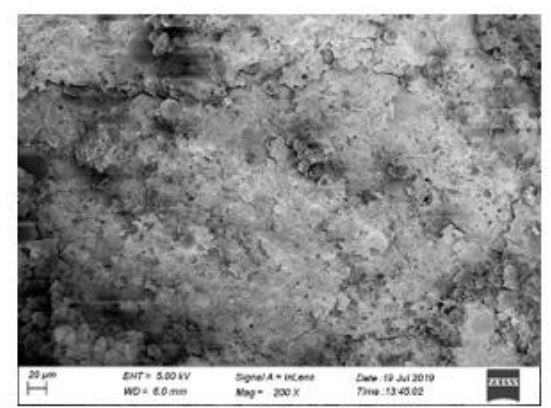

(b) FA-GBFS 70-30

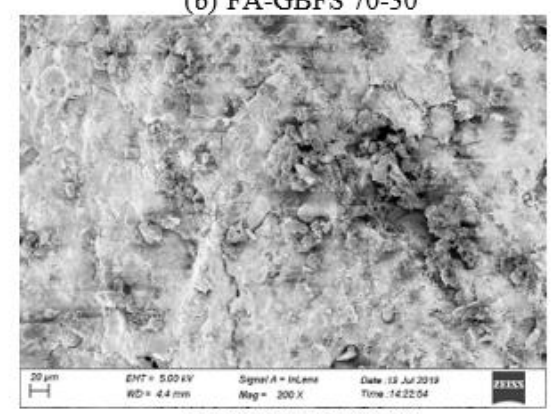

(d) FA-GBFS 30-70

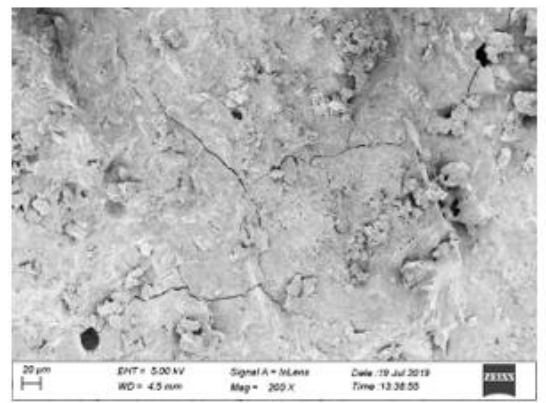

(e) FA-GBFS 0-100

Figure 7. Few representative SEM micrographs of geopolymer specimen.

The SEM micrographs of geopolymer specimens are shown in Figure 7(a-e). Figure 7(a) shows the micrograph for the specimen ID FA-GBFS 100-0, which is prepared by the reaction between the fly ash powder and an alkaline solution such as $\mathrm{NaOH}$ and $\mathrm{Na}_{2} \mathrm{SiO}_{3}$ solution. It can be observed that most of the fly ash powders fully reacted due to alkaline activation along with some unreacted powders. Few lines of cracks can also be observed. Figure 7(b-d) shows the geopolymer specimen prepared by 30, 50, 70\% fly ash and 70, 5030 $\%$ GBFS powder, respectively. From Figure 7(b), 7(c), 7(d), it can be observed that most of the particles of fly ash powders are reacted as a comparison to Figure 7(a). The addition of GBFS in fly ash powder changes the microstructure and results in hard compacted reaction products shown in Figure 7(b), 7(c), and 7(d), respectively. Very few unreacted fly ash powders 
can be observed in Figures 7(b), 7(c), and 7(d). Fig 7(e) represents the specimen that is prepared only with the GBFS powder and an alkaline solution. The specimens are filled with few numbers of pores along with cracks. The microstructure of the geopolymer specimen, which is prepared with GBFS powder, shows denser because of the increasing formation of C-S-H gel [17].

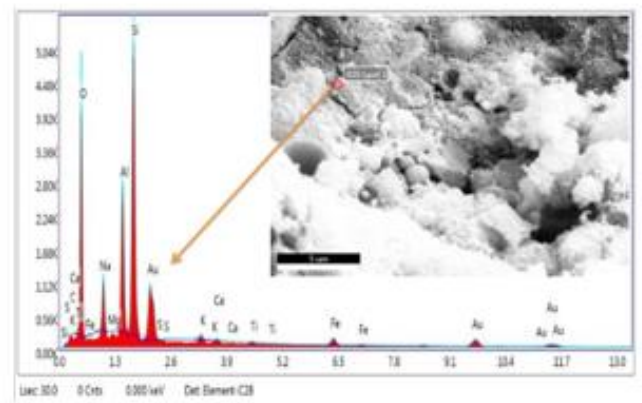

(a) FA-GBFS 100-0

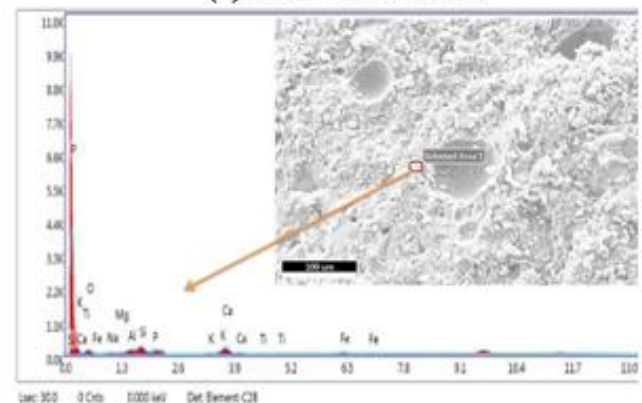

(c) FA-GBFS 50-50

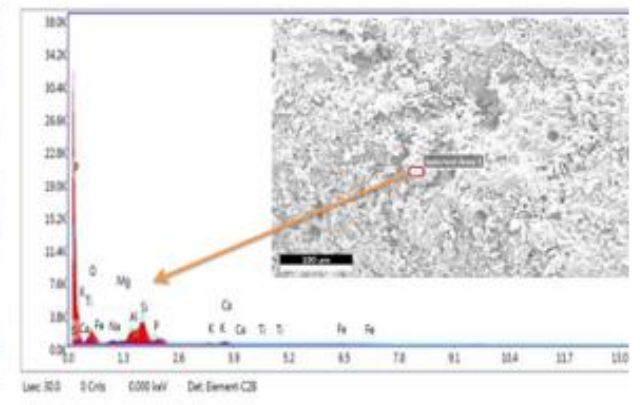

(b) FA-GBFS 70-30

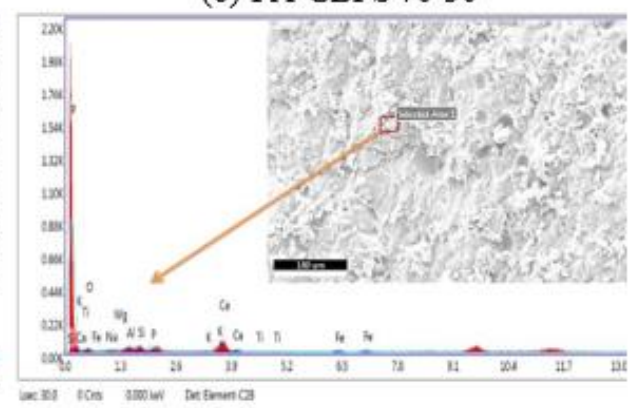

(d) FA-GBFS 30-70

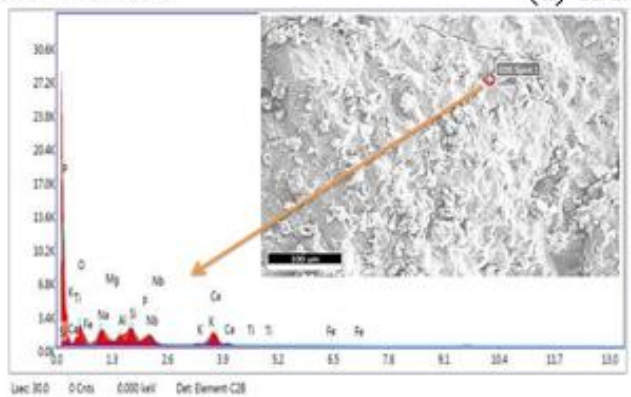

(e) FA-GBFS 0-100

Figure 8. EDS images of the geopolymer specimen ID (a) FA-GBFS 100-0, (b) FA-GBFS 70-30, (c) FA-GBFS 50-50, (d) FA-GBFS 30-70, (e) FA-GBFS 0-100.

Energy-dispersive X-ray spectroscopy analysis was performed on the geopolymer specimen to identify the constituent's presents of the geopolymerization products. Figure 8 shows the EDS images of the geopolymer specimen ID (a) FA-GBFS 100-0, (b) FA-GBFS 7030, (c) FA-GBFS 50-50, (d) FA-GBFS 30-70 and (e) FA-GBFS 0-100. The presence of various constituents such as $\mathrm{Na}, \mathrm{Al}, \mathrm{Si}$ and $\mathrm{Ca}$ can be easily observed from the EDS spectra, which confirms the presence of the sodium aluminum silicate hydrate gel (N-A-S-H gel) along with aluminum-modified calcium silicate hydrate gel (C-A-S-H gel). The class $\mathrm{F}$ fly ash powders are activated with an alkaline solution to form three dimensional N-A-S-H $\left(\mathrm{Na}_{2} \mathrm{O}-\mathrm{Al}_{2} \mathrm{O}_{3}-\mathrm{SiO}_{2}-\right.$ $\mathrm{H}_{2} \mathrm{O}$ ) type gel, and the presence of calcium-rich material GBFS further accelerates the dissolution process by releasing calcium and aluminum to form C-A-S-H $\left(\mathrm{CaO}-\mathrm{Al}_{2} \mathrm{O}_{3}-\mathrm{SiO}_{2}-\right.$ $\mathrm{H}_{2} \mathrm{O}$ ) gel [40]. The geopolymer specimen containing GBFS also shows some minor elements such as $\mathrm{Fe}, \mathrm{Mg}, \mathrm{K}$, Ti, and $\mathrm{Nb}$. 


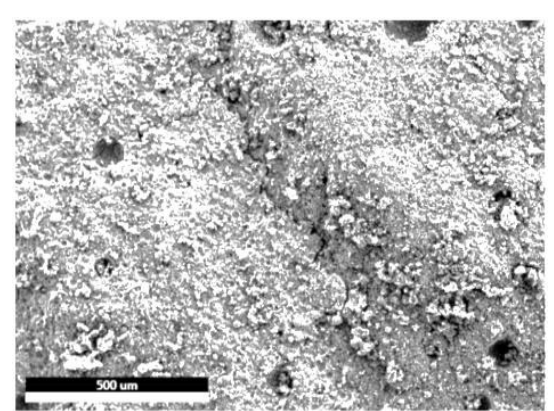

Electron image

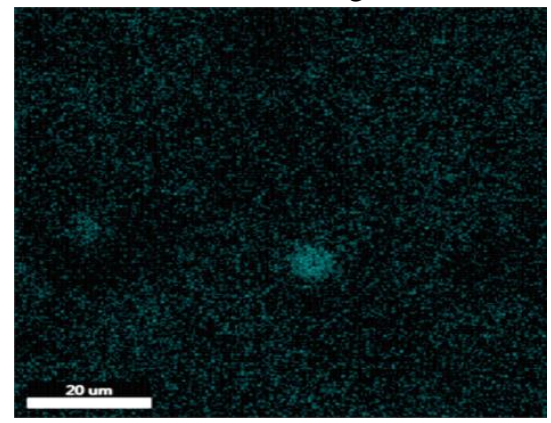

$\mathrm{Ca}$

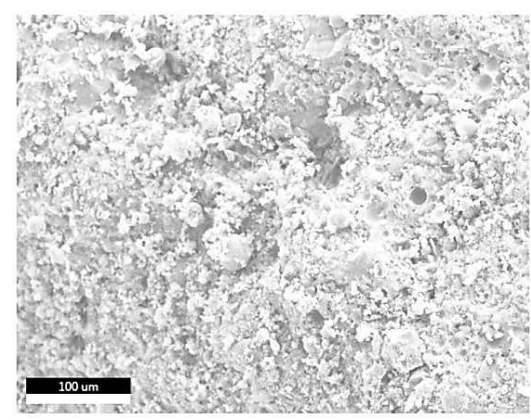

Electron image

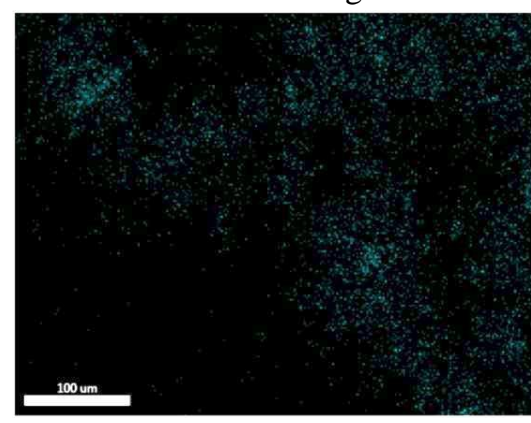

$\mathrm{Ca}$

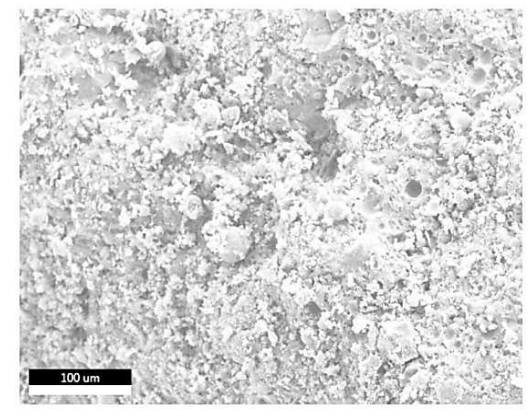

Electron image

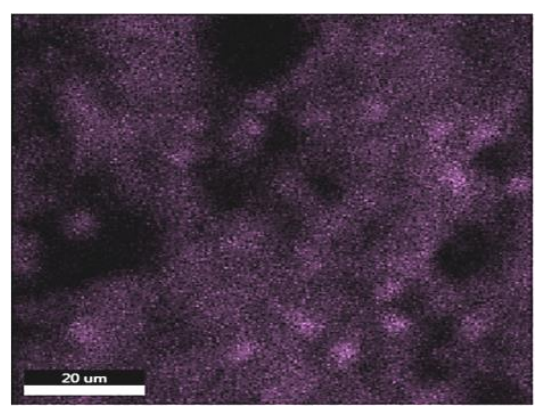

$\mathrm{Si}$

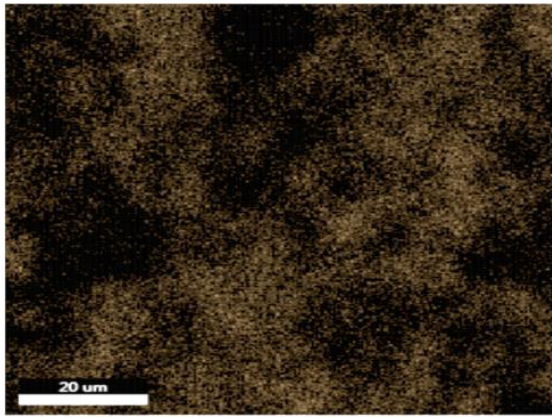

$\mathrm{Na}$

(a) FA-GBFS 100-0

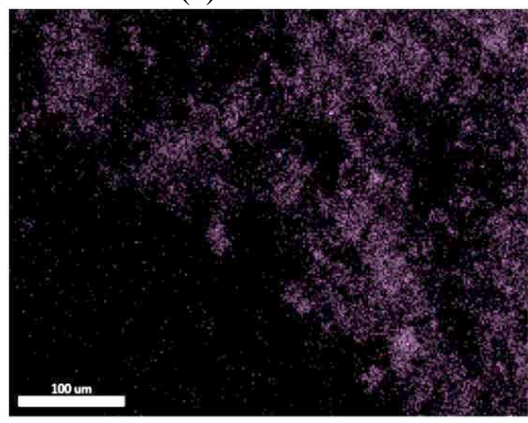

$\mathrm{Si}$

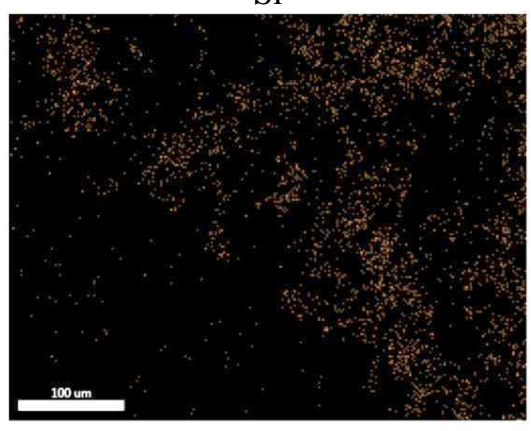

$\mathrm{Na}$

(b) FA-GBFS 70-30

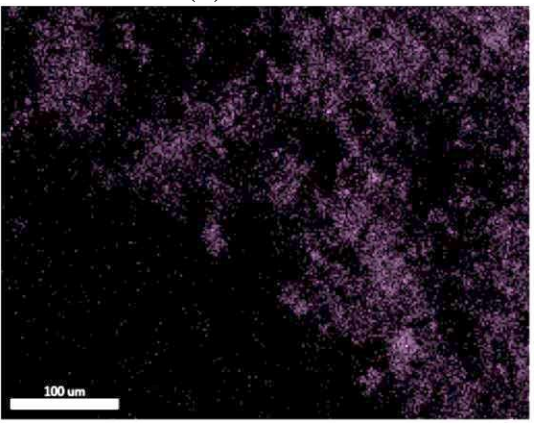

$\mathrm{Si}$

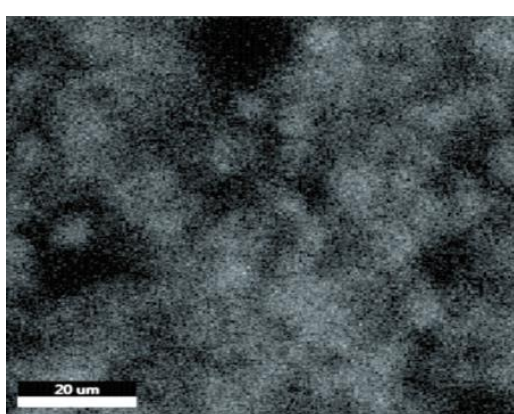

$\mathrm{Al}$

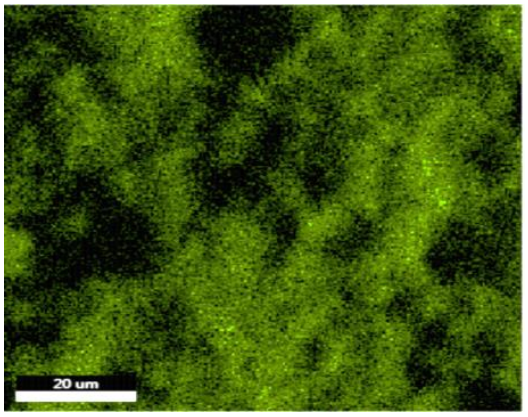

$\mathrm{O}$

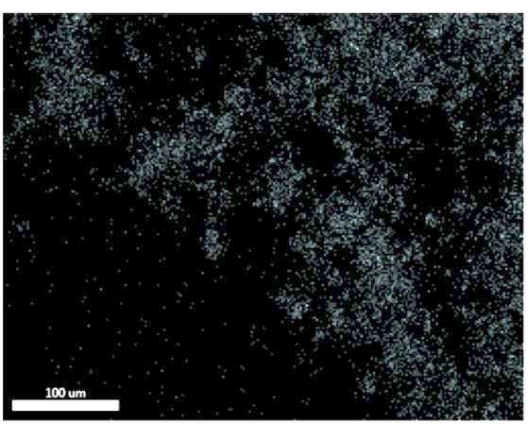

$\mathrm{Al}$

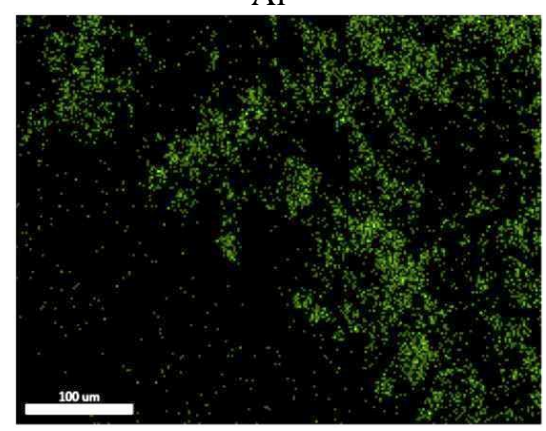

$\mathrm{O}$

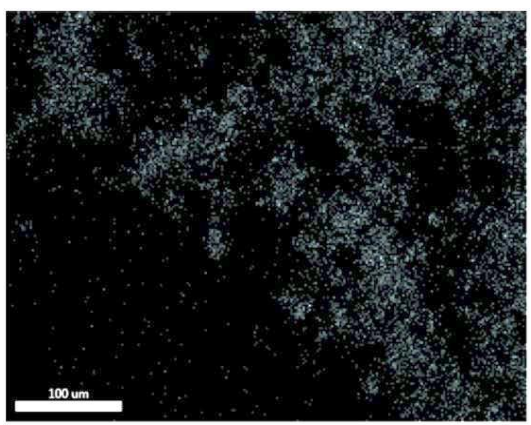

Al 


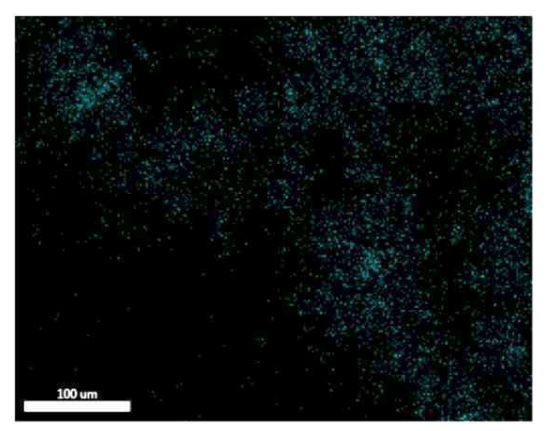

$\mathrm{Ca}$

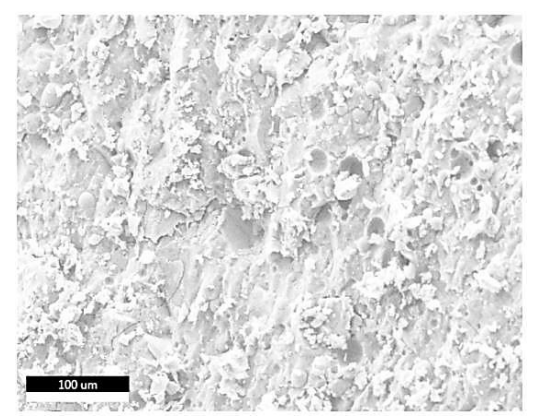

Electron image

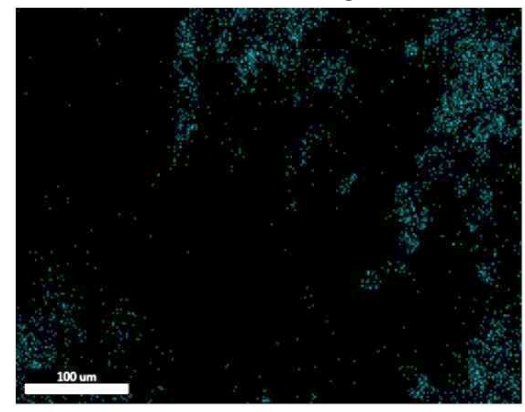

$\mathrm{Ca}$

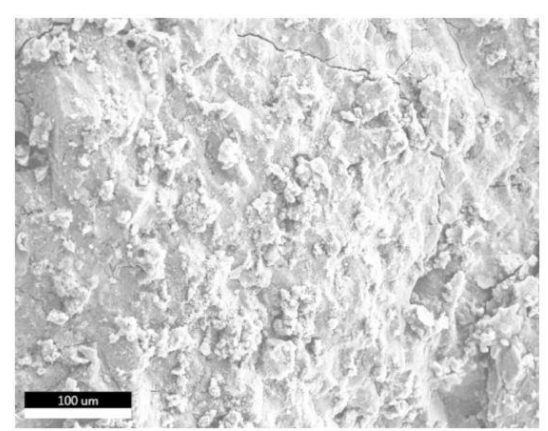

Electron image

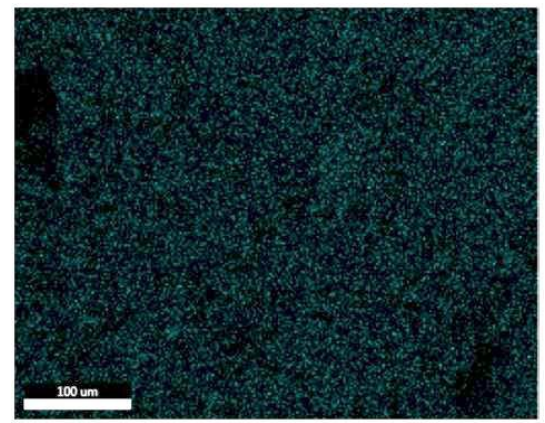

$\mathrm{Ca}$

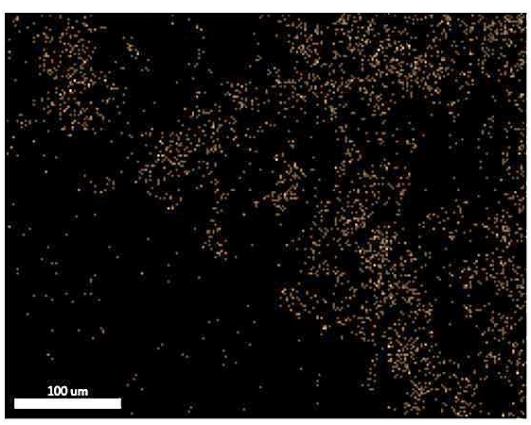

$\mathrm{Na}$

(c) FA-GBFS 50-50

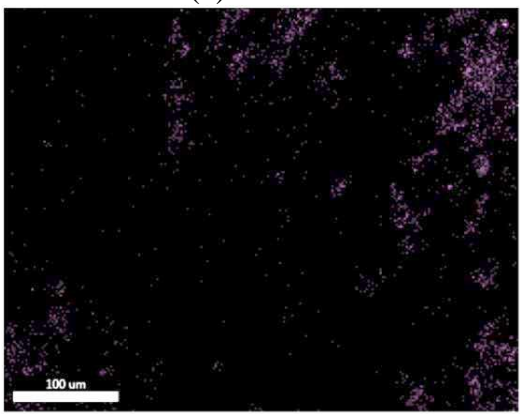

$\mathrm{Si}$

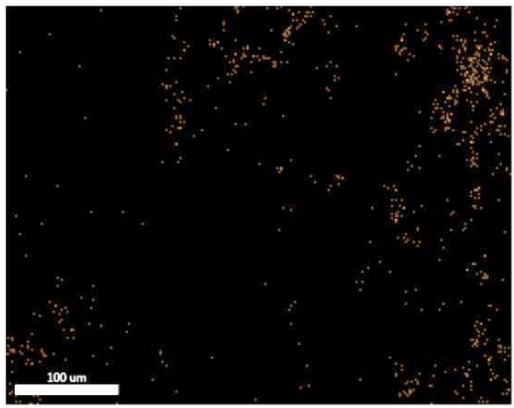

$\mathrm{Na}$

(d) FA-GBFS 30-70

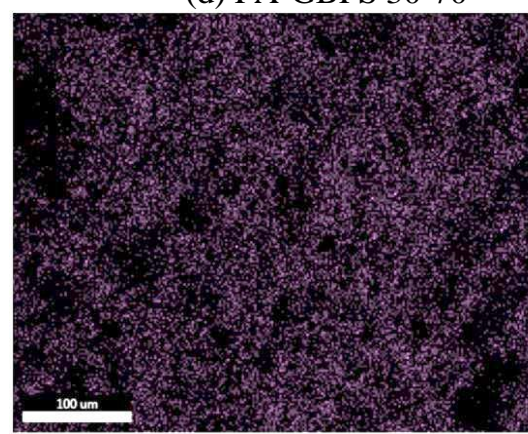

$\mathrm{Si}$

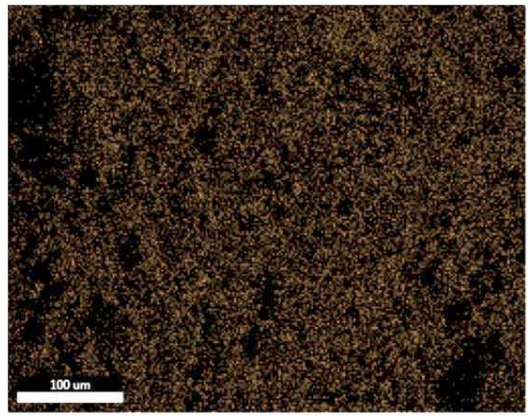

$\mathrm{Na}$

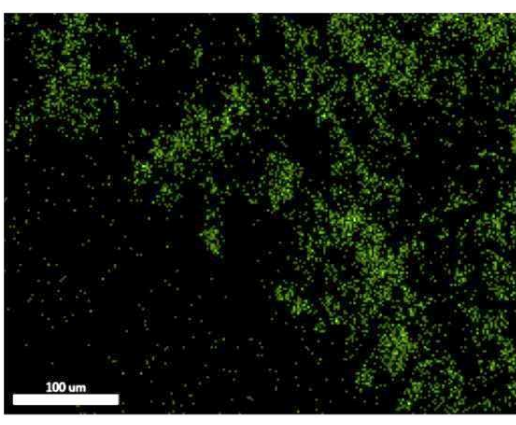

$\mathrm{O}$

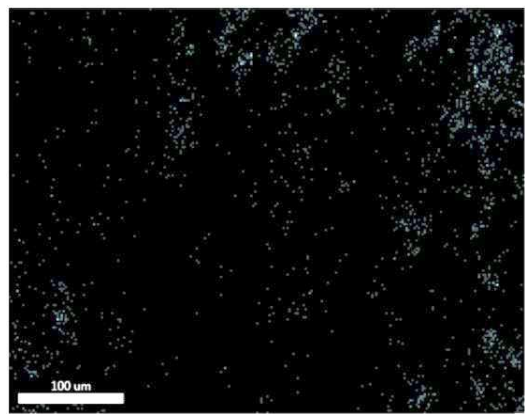

$\mathrm{Al}$

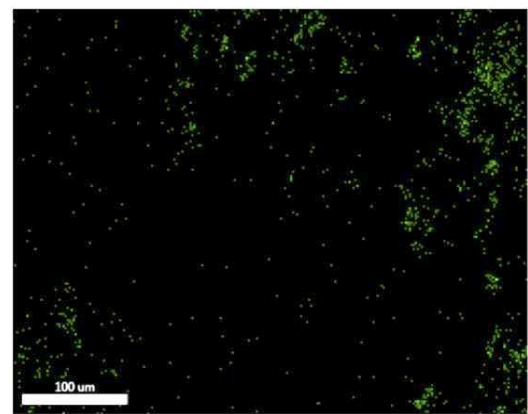

$\mathrm{O}$

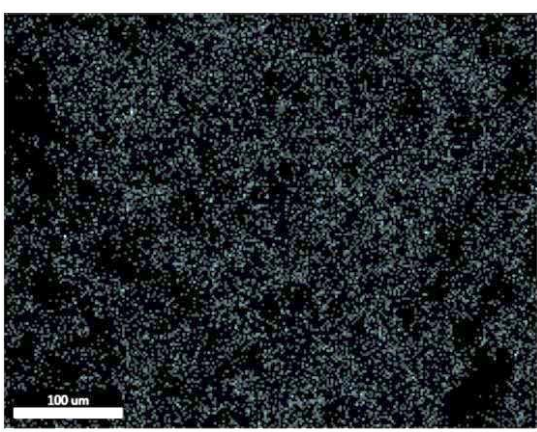

$\mathrm{Al}$

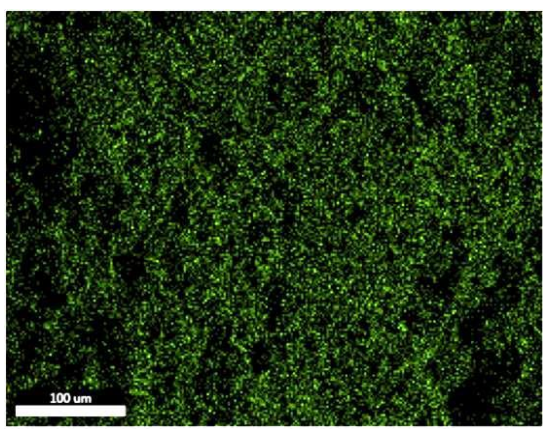

$\mathrm{O}$

(e) FA-GBFS 0-100

Figure 9. Elemental mapping of geopolymer specimen ID (a) FA-GBFS 100-0, (b) FA-GBFS 70-30, (c) FAGBFS 50-50, (d) FA-GBFS 30-70 and (e) FA-GBFS 0-100. 
Elemental mapping analysis was done using SEM equipped with EDS, which reveals the distribution of elements within the geopolymeric specimen. Figure 9 shows the elemental mapping analysis for the geopolymer specimen ID (a) FA-GBFS 100-0, (b) A-GBFS 70-30, (c) FA-GBFS 50-50, (d) FA-GBFS 30-70 and (e) FA-GBFS 0-100. The elemental mapping shows that the geopolymeric specimens ID FA-GBFS 100-0 are rich in $\mathrm{Si}, \mathrm{Al}, \mathrm{Na}$, and O, but $\mathrm{Ca}$ 's presence is less due to the class $\mathrm{F}$ fly ash powder. These elements are formed the N-A-S$\mathrm{H}$ type gel, which is hardened to the geopolymer matrix. But if we consider the specimen ID FA-GBFS 0-100, then we can observe that the distribution of $\mathrm{Ca}$ is more along with the element $\mathrm{Si}, \mathrm{Al}, \mathrm{Na}$, and $\mathrm{O}$. The presence of more $\mathrm{Ca}$ element is due to the source material GBFS powder. The incorporation of GBFS powder in fly ash powders formed the C-A-S-H type gel and the N-A-S-H type gel [41]

\section{Conclusion}

In this present work, synthesis and characterization of fly ash and GBFS based material were done by adapting geopolymer technology, and it has been observed that the addition of GBFS improves the compressive strength in fly ash-based geopolymer specimens. The improvement of compressive strength may be due to the formation of N-A-S-H gel and C-A$\mathrm{S}-\mathrm{H}$ gel. The blend composition plays an important role in strength development in fly ash and GBFS based geopolymer specimens, which were revealed by microstructural analysis. EDS spectra confirm the presence of the sodium aluminum silicate hydrate gel (N-A-S-H gel) along with aluminum-modified calcium silicate hydrate gel (C-A-S-H gel). The main reaction products for specimen ID FA-GBFS 100-0 are N-A-S-H gel, and specimen ID FA-GBFS 0100 is C-A-S-H gel. The presence of N-A-S-H and C-A-S-H gels or hybrid C-N-A-S-H gel is the main reaction product for the fly ash and ground granulated blast furnace slag-based geopolymer specimen. Elemental mapping analysis reveals the distribution of elements within the geopolymeric specimens.

\section{Funding}

This work was funded by the G.B. Pant National Institute of Himalayan Environment and Sustainable Development (IERP funded), Government of India, Sanction letter no: GBPI/IERP/17-18/44, date: $28^{\text {th }}$ March 2018.

\section{Acknowledgments}

The authors are grateful to the G.B. Pant National Institute of Himalayan Environment and Sustainable Development (IERP funded), Government of India, for supporting the project entitled "Production of geopolymer based construction material from Fly ash: An industrial waste." We are very thankful to Mr. Ekonthung Ngullie (DGM), and Mr. B N Mal at National thermal power corporation limited, Bongaigaon, Assam, India, for providing us the coal fly ash powder to carry out the experiment. The authors are also very much thankful to the Central Instrumentation Centre (CIC), Tripura University (A Central University), Agartala, Tripura, India, for allowing us to avail the facilities of FESEM and Central Instrumentation Facility (CIF), National Institute of Technology, Silchar for the use of XRD facility.

\section{Conflicts of Interest}

The authors declare no conflict of interest. 


\section{References}

1. Das, D.; Rout, P.K. Utilization of Thermal Industry Waste: From Trash to Cash. Carbon - Science and Technology 2019, 2, 43-48.

2. Lahoti, M.; Tan, K.H.; Yang, E.H. A Critical Review of Geopolymer Properties for Structural FireResistance Applications. Construction and Building Materials 2019, 221, 514-526, https://doi.org/10.1016/j.conbuildmat.2019.06.076.

3. Hassan, A.; Arif, M.; Shariq, M. A Review of Properties and Behaviour of Reinforced Geopolymer Concrete Structural Elements- A Clean Technology Option for Sustainable Development. Journal of Cleaner Production 2020, 245, https://doi.org/10.1016/j.jclepro.2019.118762.

4. Kim, B.; Lee, S. Review on Characteristics of Metakaolin-Based Geopolymer and Fast Setting. Journal of the Korean Ceramic Society 2020, 57, 368-377, https://doi.org/10.1007/s43207-020-00043-y.

5. Huseien, G.F.; Shah, K.W. Performance Evaluation of Alkali-Activated Mortars Containing Industrial Wastes as Surface Repair Materials. Journal of Building Engineering 2020, 30, https://doi.org/10.1016/j.jobe.2020.101234.

6. Junru, R.; Huiguo, C.; Ruixi, D.; Tao, S. Behavior of Combined Fly Ash/GBFS-Based Geopolymer Concrete after Exposed to Elevated Temperature. IOP Conference Series: Earth and Environmental Science 2019, 267, https://doi.org/10.1088/1755-1315/267/3/032056.

7. Generation, $\quad$ F.L.Y.A.S.H.; Utilization, $\quad$ I.T.S.; The, Http://Www.Cea.Nic.in/Reports/Others/Thermal/Tcd/Flyash_201718-Firsthalf.Pdf. 2018, 18.

8. Prasad, V.; Mehrotra, S.P.; Thareja, P. Influence of Additives, Particle Size, and Incorporation of Coarse Particles on the Shear Rheology of Concentrated Indian Coal Ash Slurries. Asia-Pacific Journal of Chemical Engineering 2019, 14, 1-11, https://doi.org/10.1002/apj.2358.

9. Yousuf, A.; Manzoor, S.O.; Youssouf, M. Fly Ash : Production and Utilization in India - An Overview. 2020, 2508, 911-921.

10. Central Electricity Authority, G. of I. CEA Annual Report 2018-19. Annual Report 2019, 248.

11. Pandey, V.; Ray, M.; Kumar, V. Assessment of Water-Quality Parameters of Groundwater Contaminated by Fly Ash Leachate near Koradi Thermal Power Plant, Nagpur. Environmental Science and Pollution Research 2020, 27, 27422-27434, https://doi.org/10.1007/s11356-019-06167-x.

12. Khan, I.; Umar, R. Environmental Risk Assessment of Coal Fly Ash on Soil and Groundwater Quality, Aligarh, India. Groundwater for Sustainable Development 2019, 8, 346-357, https://doi.org/10.1016/j.gsd.2018.12.002.

13. Toniolo, N.; Boccaccini, A.R. Fly Ash-Based Geopolymers Containing Added Silicate Waste . A Review. Ceramics International 2017, 43, 14545-14551, https://doi.org/10.1016/j.ceramint.2017.07.221.

14. Marjanović, N.; Komljenović, M.; Baščarević, Z.; Nikolić, V.; Petrović, R. Physical-mechanical and microstructural properties of alkali-activated fly ash-blast furnace slag blends. Ceramics International 2015, 41, 1421-1435, https://doi.org/10.1016/j.ceramint.2014.09.075.

15. Winnefeld, F.; Leemann, A.; Lucuk, M.; Svoboda, P.; Neuroth, M. Assessment of Phase Formation in Alkali Activated Low and High Calcium Fly Ashes in Building Materials. Construction and Building Materials 2010, 24, 1086-1093, https://doi.org/10.1016/j.conbuildmat.2009.11.007.

16. Palomo, A. Alkali-Activated Fly Ash: Effect of Thermal Curing Conditions on Mechanical and Microstructural Development - Part II. 2007, 86, 315-322, https://doi.org/10.1016/j.fuel.2006.07.010.

17. Kumar, S.; Kumar, R.; Mehrotra, S.P. Influence of Granulated Blast Furnace Slag on the Reaction, Structure and Properties of Fly Ash Based Geopolymer. Journal of Materials Science 2010, 45, 607-615, https://doi.org/10.1007/s10853-009-3934-5.

18. Yang, J.; Huang, J.; Su, Y.; He, X.; Tan, H.; Yang, W.; Strnadel, B. Eco-Friendly Treatment of Low-Calcium Coal Fly Ash for High Pozzolanic Reactivity: A Step towards Waste Utilization in Sustainable Building Material. Journal of Cleaner Production 2019, 238, 117962, https://doi.org/10.1016/j.jclepro.2019.117962.

19. Lee, N.K.; Lee, H.K. Reactivity and reaction products of alkali-activated, fly ash/slag paste. Construction and Building Materials 2015, 81, 303-312, https://doi.org/10.1016/j.conbuildmat.2015.02.022.

20. Ismail, I.; Bernal, S.A.; Provis, J.L.; San, R.; Hamdan, S.; Deventer, J.S.J. Modification of Phase Evolution in Alkali-Activated Blast Furnace Slag by the Incorporation of Fly Ash. Van Cement \& Concrete Composites 2014, 45, 125-135, https://doi.org/10.1016/j.cemconcomp.2013.09.006.

21. Saha, S.; Rajasekaran, C. Enhancement of the Properties of Fly Ash Based Geopolymer Paste by Incorporating Ground Granulated Blast Furnace Slag. Construction and Building Materials 2017, 146, 615620, https://doi.org/10.1016/j.conbuildmat.2017.04.139.

22. Samantasinghar, S.; Singh, S. Effects of Curing Environment on Strength and Microstructure of AlkaliActivated Fly Ash-Slag Binder. Construction and Building Materials 2020, 235, https://doi.org/10.1016/j.conbuildmat.2019.117481.

23. Yousefi Oderji, S.; Chen, B.; Ahmad, M.R.; Shah, S.F.A. Fresh and Hardened Properties of One-Part Fly Ash-Based Geopolymer Binders Cured at Room Temperature: Effect of Slag and Alkali Activators. Journal of Cleaner Production 2019, 225, 1-10, https://doi.org/10.1016/j.jclepro.2019.03.290. 
24. Xu, H.; Gong, W.; Syltebo, L.; Izzo, K.; Lutze, W.; Pegg, I.L. Effect of Blast Furnace Slag Grades on Fly Ash Based Geopolymer Waste Forms. Fuel 2014, 133, 332-340, https://doi.org/10.1016/j.fuel.2014.05.018.

25. Firdous, R.; Stephan, D. Effect of Silica Modulus on the Geopolymerization Activity of Natural Pozzolans. Construction and Building Materials 2019, 219, 31-43, https://doi.org/10.1016/j.conbuildmat.2019.05.161.

26. Shekhawat, P.; Sharma, G.; Martand, R. Strength Behavior of Alkaline Activated Eggshell Powder and Flyash Geopolymer Cured at Ambient Temperature. Construction and Building Materials 2019, 223, 11121122, https://doi.org/10.1016/j.conbuildmat.2019.07.325.

27. Xie, J.; Wang, J.; Rao, R.; Wang, C.; Fang, C. Effects of combined usage of GGBS and fly ash on workability and mechanical properties of alkali activated geopolymer concrete with recycled aggregate. Composites Part B: Engineering 2019, 164, 179-190, https://doi.org/10.1016/j.compositesb.2018.11.067.

28. Fauzi, A.; Fadhil, M.; Malkawi, A.B.; Mustafa, M.; Bakri, A. Study of Fly Ash Characterization as a Cementitious Material. 2016, 148, 487-493, https://doi.org/10.1016/j.proeng.2016.06.535.

29. Hsu, S.; Chi, M.; Huang, R. Effect of Fineness and Replacement Ratio of Ground Fly Ash on Properties of Blended Cement Mortar. Construction and Building Materials 2018, 176, 250-258, https://doi.org/10.1016/j.conbuildmat.2018.05.060.

30. Moghaddam, F.; Sirivivatnanon, V.; Vessalas, K. The Effect of Fly Ash Fineness on Heat of Hydration, Microstructure, Flow and Compressive Strength of Blended Cement Pastes. Case Studies in Construction Materials 2019, 10, https://doi.org/10.1016/j.cscm.2019.e00218.

31. Kim, M.S.; Jun, Y.; Lee, C.; Oh, J.E. Use of $\mathrm{CaO}$ as an Activator for Producing a Price-Competitive NonCement Structural Binder Using Ground Granulated Blast Furnace Slag. Cement and Concrete Research 2013, 54, 208-214, https://doi.org/10.1016/j.cemconres.2013.09.011.

32. Gruskovnjak, A.; Lothenbach, B.; Winnefeld, F.; Figi, R.; Ko, S.C.; Adler, M.; Mäder, U. Hydration Mechanisms of Super Sulphated Slag Cement. Cement and Concrete Research 2008, 38, 983-992, https://doi.org/10.1016/j.cemconres.2008.03.004.

33. Singla, R.; Kumar, S.; Alex, T.C. Reactivity Alteration of Granulated Blast Furnace Slag by Mechanical Activation for High Volume Usage in Portland Slag Cement. Waste and Biomass Valorization 2020, 11, 2983-2993, https://doi.org/10.1007/s12649-019-00580-6.

34. Pan, Z.; Tao, Z.; Cao, Y.F.; Wuhrer, R.; Murphy, T.; Composites, C.; Tao, Z.; Cao, Y.F.; Wuhrer, R.; Murphy, T. Compressive Strength and Microstructure of Alkali-Activated Fly Ash/Slag Binders at High Temperature. Cement and Concrete Composites 2017, 86, 9-11, https://doi.org/10.1016/j.cemconcomp.2017.09.011.

35. Ismail, I.; Bernal, S.A.; Provis, J.L.; San Nicolas, R.; Hamdan, S.; Van Deventer, J.S.J. Modification of Phase Evolution in Alkali-Activated Blast Furnace Slag by the Incorporation of Fly Ash. Cement and Concrete Composites 2014, 45, 125-135, https://doi.org/10.1016/j.cemconcomp.2013.09.006.

36. Sukmak, P.; Kunchariyakun, K.; Sukmak, G.; Horpibulsuk, S.; Kassawat, S.; Arulrajah, A. Strength and Microstructure of Palm Oil Fuel Ash-Fly Ash-Soft Soil Geopolymer Masonry Units. Journal of Materials in Civil Engineering 2019, 31, 1-13, https://doi.org/10.1061/(ASCE)MT.1943-5533.0002809.

37. Rożek, P.; Król, M.; Mozgawa, W. Spectroscopic Studies of Fly Ash-Based Geopolymers. Spectrochimica Acta - Part A: Molecular and Biomolecular Spectroscopy 2018, 198, 283-289, https://doi.org/10.1016/j.saa.2018.03.034.

38. Shadnia, R.; Zhang, L. Experimental Study of Geopolymer Synthesized with Class F Fly Ash and LowCalcium Slag. Journal of Materials in Civil Engineering 2017, 29, https://doi.org/10.1061/(asce)mt.19435533.0002065 .

39. Cai, J.; Li, X.; Tan, J.; Vandevyvere, B. Thermal and Compressive Behaviors of Fly Ash and MetakaolinBased Geopolymer. Journal of Building Engineering 2020, 30, https://doi.org/10.1016/j.jobe.2020.101307.

40. Ismail, I.; Bernal, S.A.; Provis, J.L.; Hamdan, S.; Van Deventer, J.S.J. Drying-Induced Changes in the Structure of Alkali-Activated Pastes. Journal of Materials Science 2013, 48, 3566-3577, https://doi.org/10.1007/s10853-013-7152-9.

41. Guo, X.; Shi, H.; Dick, W.A. Compressive Strength and Microstructural Characteristics of Class C Fly Ash Geopolymer. Cement and Concrete Composites 2010, 32, 142-147, https://doi.org/10.1016/j.cemconcomp.2009.11.003. 